\title{
Time series of hospitalizations of adolescents due to mental and behavioral disorders
}

\author{
Série temporal das internações de adolescentes por transtornos mentais e comportamentais
}

Serie temporal de las internaciones de adolescentes por trastornos mentales y comportamentales

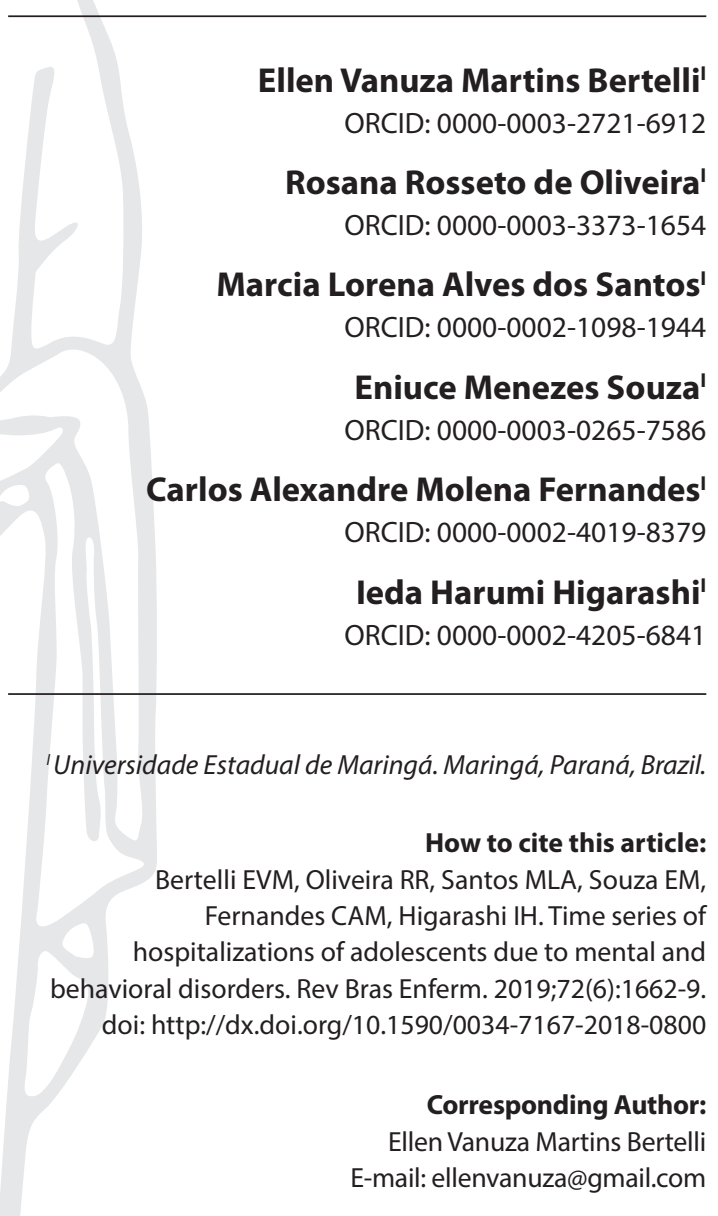

Submission: 10-19-2018

Approval: 02-17-2019

\section{ABSTRACT}

Objective: to analyze the trend of hospitalizations of adolescents due to mental and behavioral disorders in Paraná, from 1998 to 2015. Method: ecological study of time series. Data were analyzed by means of segmented linear regression modeling for time series, estimated for each of the four health macro-regions. Results: the East macro-region showed a greater trend to increase hospitalizations from January 1998 to November 2003 $\left(\beta_{1}=0.006, p<0.001\right)$. In other macro-regions, there were similar trends with a sudden increase in February 2010, but with a further gradual decrease until December 2015. In the quadrennium $2012-2015,38.06 \%$ of the hospitalizations lasted 29 or more days, and in the Northwest macro-region, hospitalizations lasted for up to seven days. The main cause of hospitalization was the use of alcohol and other drugs. Conclusion: there is a need to strengthen health actions to prevent drug use and improvements in the care network. Descriptors: Adolescent, Hospitalized; Mental disorders; Epidemiology; Health Policy; Mental Health.

\section{RESUMO}

Objetivo: analisar a tendência das internações por transtornos mentais e comportamentais em adolescentes no Paraná, no período de 1998 a 2015. Método: estudo ecológico de séries temporais. Os dados foram analisados através de modelagem de regressão linear segmentada para séries temporais, estimada para cada uma das quatro macrorregiões de saúde. Resultados: a macrorregional Leste mostrou maior tendência de aumento de internações de janeiro de 1998 a novembro de $2003\left(\beta_{1}=0,006, p<0,001\right)$. Nas outras macrorregionais, tendências similares com aumento repentino em fevereiro de 2010, mas com posterior decréscimo gradativo até dezembro de 2015. No quadriênio 20122015, 38,06\% das internações duraram 29 ou mais dias, e na macrorregional Noroeste, predominaram as internações com duração de até sete dias. A principal causa de internação foi o uso de álcool e outras drogas. Conclusão: há necessidade de fortalecimento de ações de saúde de prevenção ao uso de drogas e melhorias na rede de atendimento.

Descritores: Adolescente Hospitalizado; Transtornos Mentais; Epidemiologia; Política de Saúde; Saúde Mental.

\section{RESUMEN}

Objetivo: analizar la tendencia de las internaciones por trastornos mentales y comportamentales en adolescentes en el estado de Paraná entre 1998 y 2015. Método: estudio ecológico de series temporales. Los datos fueron analizados a través de un modelado de regresión lineal segmentada para series temporales, estimada para cada una de los cuatro macrorregiones de salud. Resultados: la macrorregional Este mostró mayor tendencia de aumento de internaciones de enero 1998 a noviembre 2003 $(\beta 1=0,006 ; p<0,001)$. En las otras macrorregionales, hubieron tendencias similares, con un aumento repentino en febrero 2010, pero con posterior descenso gradual hasta diciembre 2015. En el cuadrienio 2012-2015, el 38,06\% de las internaciones duraron 29 o más días, y en la macrorregional Noroeste predominaron las internaciones con una duración de hasta siete días. La principal causa de internación fue el uso de alcohol y otras drogas. Conclusión: Jay que fortalecer las acciones de salud de prevención al uso de drogas y mejorías en la red de atención.

Descriptores: Adolescente Hospitalizado; Trastornos Mentales; Epidemiología; Política de Salud; Salud Mental. 


\section{INTRODUCTION}

Chronic Noncommunicable Diseases (CNCD) have been responsible for the greatest burden of diseases in Brazil ${ }^{(1)}$. Among CNCD, cases of mental and behavioral disorders in children and adolescents have been drawing the attention of the scientific community ${ }^{(2)}$. It is not uncommon the appearance in this age of pictures, such as anxiety, depression, conduct disorders, among others. Studies indicate that it is in adolescence that the first contact with psychoactive substances ${ }^{(2)}$ occurs, more and more prematurely ${ }^{(3-4)}$, generating acute episodes of intoxication that require hospital treatment ${ }^{(5)}$.

A recent Brazilian study identified a prevalence of $30.0 \%$ of anxiety and depressive disorders in adolescence ${ }^{(6)}$. A similar result was found in Portugal, which presented an index of $31.2 \%$ of adolescents with symptoms of depression ${ }^{(7)}$.

Mental and behavioral disorders have their outpatient treatment, performed in specialized services or in Primary Care itself; However, acute conditions require hospital treatment through hospitalization ${ }^{(8)}$. During 2016, 14,499 hospitalizations were registered in Brazil due to mental and behavioral disorders in the age group of 10 to 19 years. In the state of Paraná, there were 998 hospitalizations in the same period and age group. These figures place these disorders as the $11^{\text {th }}$ cause of hospitalizations in the age group of 10 to 19 years in Brazil and the $10^{\text {th }}$ cause of hospitalization in Paraná, excluding hospitalizations due to pregnancy, delivery and puerperium ${ }^{(9)}$.

Mental and behavioral disorders are significant aggravations in adolescence, with a shortage of studies that address hospitalizations specifically in adolescence.

\section{OBJECTIVE}

To analyze the trend of hospitalizations of adolescents due to mental and behavioral disorders in the state of Paraná.

\section{METHOD}

\section{Ethical aspects}

The study followed the norms of research involving human beings, according to Resolution 466/2012, and had its research project approved by the Research Ethics Committee of the Universidade Estadual do Centro Oeste.

\section{Design, place of study and period}

This is an ecological study of time series, from 1998 to 2015, on hospitalizations of adolescents due to mental and behavioral disorders, carried out in the state of Paraná in 2017.

\section{Population; inclusion and exclusion criteria}

All hospitalizations performed by the Brazilian Unified Health System (SUS - Sistema Único de Saúde) were caused by mental and behavioral disorders in adolescents living in Paraná. For the adolescent population delimitation, the criteria adopted by the
Statute of the Child and Adolescent (ECA - Estatuto da Criança e do Adolescente) were used, which considers adolescence as the period between 12 and 18 years of age ${ }^{(10)}$. In 2016, adolescents from 12 to 17 years of Paraná corresponded to $9.77 \%$ of the total population $^{(111)}$. Paraná has 399 municipalities, organized into 22 Health Regions, aggregated in four large macro-regional health: East, North, West and Northwest ${ }^{(6)}$.

All the information contained in the Inpatient Hospital Authorization (AlH - Autorizações de Internação Hospitalar), processed by the Hospital Information System of the Brazilian Unified Health System (HIS/SUS) and available on the website of DATASUS (Information Technology Department of the Brazilian Public Health Care System).

\section{Study protocol}

Data was accessed through the Tabwin data tab and later converted into files compatible with the Excel program. For the construction of the database, all hospitalizations of adolescents living in Paraná from 1998 to 2015, according to the main diagnosis of Chapter V - Mental and Behavioral Disorders (codes F00-F99) of the Statistical International Classification of Diseases (ICD-10).

Next, hospitalizations were aggregated by regional health, identifying each municipality by the Code of the Brazilian Institute of Geography and Statistics (IBGE - Instituto Brasileiro de Geografia e Estatística). In the absence of this code, ZIP Code was used. $170 \mathrm{AlHs}$ were discarded because they did not live in Paraná; and 133 because they did not allow the identification of the municipality of origin.

In order to calculate the hospitalization rate, ratio between the monthly number of hospitalizations with the diagnosis of mental and behavioral disorder was used, and the population of the same age group and year, multiplied by 10,000 . It is valid to clarify that data regarding the population in the age group were available and were extracted from DATASUS only until 2012. Thus, to obtain the values of 2013, 2014 and 2015, a cubic polynomial curve was fitted in the annual population series in order to project its behavior. Then, the mean between the cubic polynomial curve projection values and the values obtained by the naive projection (repetition of the observed value in 2012) was done, thus providing the annual population for 2013, 2014 and 2015.

\section{Analysis of results, and statistics}

Data analysis was performed using a linear regression model segmented into time series, where yi is the monthly hospitalization rate, $y_{i}$ is the variable (time from January 1998 to December 2015), $\beta_{j}$ is the vector of parameters to be estimated and $j$ denotes the index of each of the $m+1$ segments obtained after the identification and estimation of the $m$ structural change points, that is, changes in mean level or trend. The random variability not explained by the model is represented by $\varepsilon i$, which must be normally distributed and random.

$$
y_{i}=t_{i}^{\prime} \beta_{j}+\varepsilon_{i}, i=i_{j-1}+1, \ldots, i_{j^{\prime}} j=1, \ldots, m+1
$$


In practice, points of change ij are rarely known, so it is necessary to identify and estimate them. $\beta j$ parameters in the model presented may represent the trend in a given follow-up (time period), the change in the trend in relation to an earlier followup, or a change in the mean level of the series. Estimating the respective standard errors of such parameters, it is possible to verify their statistical significance at the $5 \%$ level. Because it was a regression model for time series, it was necessary to verify the presence of serial autocorrelation in the residues, which could be diagnosed by the Ljung-Box and Breusch-Godfrey tests.

The segmented linear regression model was estimated separately for each of the four time series analyzed for the four macroregions of health in the state of Paraná. The implementation to estimate the models and perform the analyzes was done in $\mathrm{R}$ language, version 3.3.1.

\section{RESULTS}

A total of 22,121 hospitalizations due to mental and behavioral disorders of adolescents living in the state of Paraná, from 1998 to 2015, were distributed among the four macro-regional health services in the state: East (12,518), Northwest $(3,699)$, West $(3,511)$, and North $(2,393)$.

There was a great variation in hospitalization rates between the years and the regions of the state, as can be observed in Figure 1.

Figure 2 identifies the structural changes and the trend analysis of hospitalizations for the four macro-regions. The adjusted models are represented in red line.

For the East macro-region, the mean hospitalization rate estimated for the month of January 1998, represented by the intercept of the

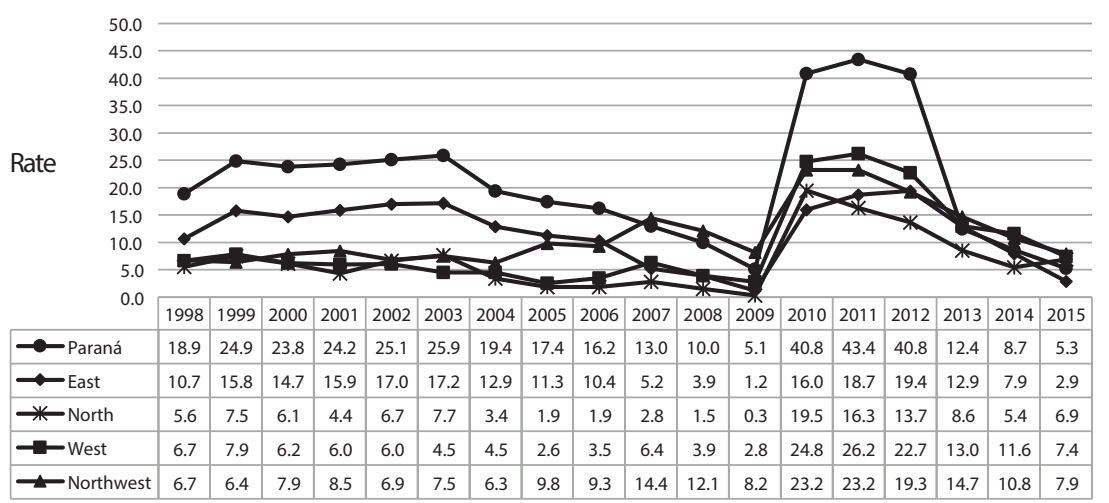

Figure 1 - Rate of hospitalizations due to mental and behavioral disorders of adolescents living in the state of Paraná, according to macro-regional health, Paraná, Brazil, 2017 model, was approximately one in 10,000 people/month $\left(\beta_{0}=1.008\right.$, $p<0.001$ ). In November 2003, when a structural change occurred, the mean rate was close to 1.5 and began to suffer a decreasing trend $\left(\beta_{2}=-0.027, p<0.001\right)$ until December 2009. In January 2010, there was a sudden change in the mean level of hospitalization series, bringing the mean hospitalizations from 0.01 to 1.58. Considering the change point estimated in February 2010, the trend remained practically stable until March $2013\left(\beta_{3}=-0.002, p<0.001\right)$, when it fell more rapidly $\left(\beta_{4}=-0.048, p<0.001\right)$ (Table 1$)$.

In the North, West and Northwest macro-regions, trends are quite similar, especially since February 2010, when there was also a sudden increase in hospitalizations $(1,792,2,152$ and 1,366, respectively), but with a subsequent gradual decrease until December 2015, with significant trends of $-0.014 ;-0.027$ and -0.024 respectively. From January 1998 to October 2003, hospitalizations, which were approximately 0.6 , in the North and West macroregions, decreased to the rate of -0.002 per month. This rate was maintained until December 2009 for the West macro-region but declined more rapidly thereafter to the North macro-region $\left(\beta_{3}=\right.$ $-0.006, p=0.012)$. In the Northwest macro-region, although the mean number of hospitalizations was also close to 0.6 in January $1998\left(\beta_{0}=0.562, p<0.001\right)$, there was an increase until December 2009 with a trend of $0.002(p<0.001)$ (Table 1$)$.

Regarding the mean length of hospitalizations in the state, the highest prevalence was for the period from 8 to 28 days, corresponding to $57.81 \%$ of hospitalizations in the first four-year period (1998-2001) and 40.15\% in the second quadrennium. However, in the last quadrennium (2012-2015), most hospitalizations (38.06\%) had length greater than or equal to 29 days (Table 2).

East macro-region had the same behavior as the state, with the mean length of most hospitalizations ranging from 8 to 28 days in the first four years, and in the quadrennium 2012-2015, $53.14 \%$ of hospitalizations lasted more than 29 days. In North and West macro-regions, the highest mean length of hospital stay in all four-year periods was 8 to 28 days. Northwest macro-region presented different behavior regarding the length of hospitalization, with $49.55 \%$ of hospitalizations lasting from 8 to 28 days in the first four years, and the majority of hospitalizations with length of 0 to 7 days in the second and third quadrennium $(52.81 \%$ and $44.22 \%$, respectively) (Table 2 ).
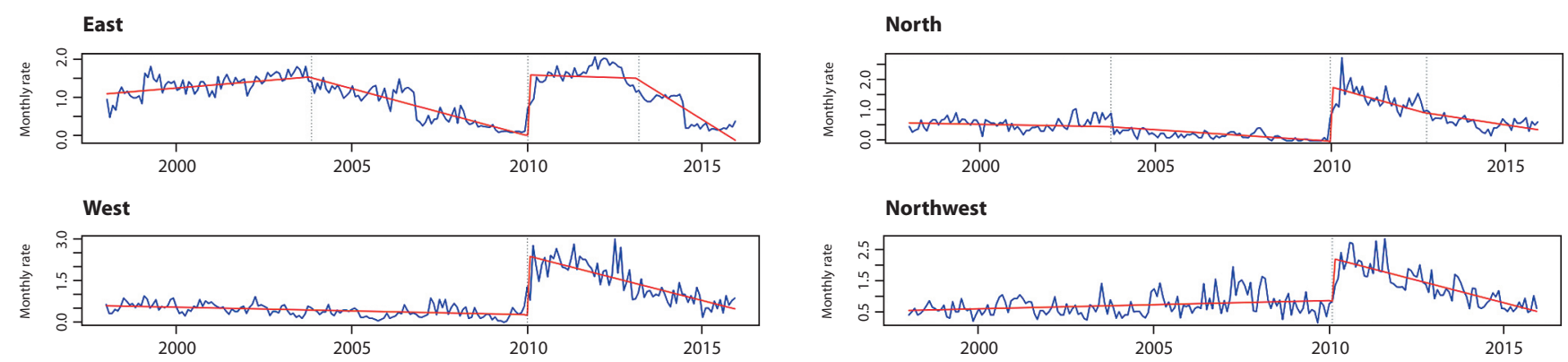

Figure 2 - Time series of hospitalizations of adolescents due to mental and behavioral disorders, according to macro-regional health, Paraná, Brazil, 2017 
Table 1 - Segmented linear regression models of hospitalization of adolescents rates due to mental and behavioral disorders, according to macro-regional health, Paraná, Brazil, 2017

\begin{tabular}{|c|c|c|c|c|c|}
\hline Parameters & Estimate & $\begin{array}{l}\text { Standard } \\
\text { Error }\end{array}$ & t value & $p$ value & Trend \\
\hline \multicolumn{6}{|l|}{ East } \\
\hline$\beta_{0}$ & 1.088 & 0.055 & 19.838 & $<0.001$ & 1.088 \\
\hline$\beta_{1}$ & 0.006 & 0.001 & 5.587 & $<0.001$ & 0.006 \\
\hline$\beta_{2}$ & -0.027 & 0.002 & -13.845 & $<0.001$ & -0.02 \\
\hline$\beta_{3}$ & 1.571 & 0.094 & 16.646 & $<0.001$ & - \\
\hline$\beta_{4}$ & 0.018 & 0.003 & 5.628 & $<0.001$ & -0.002 \\
\hline$\beta_{5}$ & -0.045 & 0.006 & -8.032 & $<0.001$ & -0.048 \\
\hline \multicolumn{6}{|l|}{ North } \\
\hline$\beta_{0}$ & 0.58 & 0.05 & 11.679 & $<0.001$ & 0.58 \\
\hline$\beta_{1}$ & -0.002 & 0.001 & -1.719 & 0.087 & -0.002 \\
\hline$\beta_{2}$ & -0.004 & 0.002 & -2.526 & 0.012 & -0.006 \\
\hline$\beta_{3}$ & 1.792 & 0.089 & 20.106 & $<0.001$ & - \\
\hline$\beta_{4}$ & -0.02 & 0.003 & -5.938 & $<0.001$ & -0.026 \\
\hline$\beta_{5}$ & 0.012 & 0.005 & 2.344 & 0.02 & -0.014 \\
\hline \multicolumn{6}{|l|}{ West } \\
\hline$\beta_{0}$ & 0.6 & 0.05 & 11.973 & $<0.001$ & 0.6 \\
\hline$\beta_{1}$ & -0.002 & 0.001 & -3.773 & $<0.001$ & -0.002 \\
\hline$\beta_{2}$ & 2.152 & 0.088 & 24.359 & $<0.001$ & - \\
\hline$\beta_{3}$ & -0.025 & 0.002 & -13.478 & $<0.001$ & -0.027 \\
\hline \multicolumn{6}{|l|}{ Northwest } \\
\hline$\beta_{0}$ & 0.562 & 0.054 & 10.448 & $<0.001$ & 0.562 \\
\hline$\beta_{1}$ & 0.002 & 0.001 & 3.417 & 0.001 & 0.002 \\
\hline$\beta_{2}$ & 1.366 & 0.096 & 14.288 & $<0.001$ & - \\
\hline$\beta_{3}$ & -0.026 & 0.002 & -12.998 & $<0.001$ & -0.024 \\
\hline
\end{tabular}

The main causes of hospitalizations in Paraná were mental and behavioral disorders resulting from the use of psychoactive substances, reaching $64.35 \%$ of hospitalizations in the quadrennium 2012-2015. In East and West macro-regions, psychoactive substance use disorders were also the main cause of hospitalization throughout the series, accounting for most hospitalizations in all four-year periods. Northwest macro-region had schizophrenia and schizotypal and delusional disorders in the first quadrennium (1998-2001) as determinants of hospitalizations (37.61\%). North macro-region presented schizophrenia and schizotypal and delusional disorders as the most prevalent cases in the first two quadrennium (1998-2001 and 2005-2008), and psychoactive substance use disorders as the main cause of hospitalization only in the last quadrennium (2012-2015), reaching $71.43 \%$ of hospitalizations in this period (Table 3 ).

\section{DISCUSSION}

Paraná and its four macro-regions of health showed a decline in the time series of hospitalizations of adolescents due to mental and behavioral disorders from 1998 to 2009. However, there was an abrupt increase of these hospitalizations in 2010, with a subsequent decline as of 2011. In the last years of the time series, there was a higher prevalence of hospitalizations with residence time of more than 29 days. The main diagnosis of intentions was the use of psychoactive substances both for Paraná as a whole and for macro-regional health.

Table 2 - Distribution of the days of hospitalization of adolescents due to mental and behavioral disorders, according to macro-regional health, Paraná, Brazil, 2017

\begin{tabular}{|c|c|c|c|c|c|c|c|c|}
\hline & \multicolumn{2}{|c|}{$1998-2001$} & \multicolumn{2}{|c|}{$2005-2008$} & \multicolumn{2}{|c|}{$2012-2015$} & \multicolumn{2}{|c|}{ Total } \\
\hline & $\mathbf{n}$ & $\%$ & $\mathbf{n}$ & $\%$ & $\mathbf{n}$ & $\%$ & $\mathbf{n}$ & $\%$ \\
\hline \multicolumn{9}{|l|}{ Paraná } \\
\hline 0 a 7 days & 932 & 18.84 & 1273 & 39.01 & 1257 & 24.30 & 3462 & 25.87 \\
\hline 8 a 28 days & 2860 & 57.81 & 1310 & 40.15 & 1947 & 37.64 & 6117 & 45.71 \\
\hline$\geq 29$ days & 1155 & 23.35 & 680 & 20.84 & 1969 & 38.06 & 3804 & 28.42 \\
\hline Total & 4947 & 36.96 & 3263 & 24.38 & 5173 & 38.65 & 13383 & 100.00 \\
\hline \multicolumn{9}{|c|}{ East macro-region } \\
\hline 0 a 7 days & 646 & 19.55 & 733 & 37.86 & 364 & 15.14 & 1743 & 22.80 \\
\hline 8 a 28 days & 2003 & 60.61 & 856 & 44.21 & 763 & 31.73 & 3622 & 47.37 \\
\hline$\geq 29$ days & 656 & 19.85 & 347 & 17.92 & 1278 & 53.14 & 2281 & 29.83 \\
\hline Total & 3305 & 43.22 & 1936 & 25.32 & 2405 & 31.45 & 7646 & 100.00 \\
\hline \multicolumn{9}{|c|}{ North macro-region } \\
\hline 0 a 7 days & 84 & 16.83 & 44 & 27.50 & 168 & 25.00 & 296 & 22.24 \\
\hline 8 a 28 days & 274 & 54.91 & 60 & 37.50 & 304 & 45.24 & 638 & 47.93 \\
\hline$\geq 29$ days & 141 & 28.26 & 56 & 35.00 & 200 & 29.76 & 397 & 29.83 \\
\hline Total & 499 & 37.49 & 160 & 12.02 & 672 & 50.48 & 1331 & 100.00 \\
\hline \multicolumn{9}{|c|}{ West macro-region } \\
\hline 0 a 7 days & 96 & 16.49 & 64 & 18.34 & 300 & 26.43 & 460 & 22.27 \\
\hline 8 a 28 days & 305 & 52.41 & 153 & 43.84 & 554 & 48.81 & 1012 & 48.98 \\
\hline$\geq 29$ days & 181 & 31.10 & 132 & 37.82 & 281 & 24.76 & 594 & 28.75 \\
\hline Total & 582 & 28.17 & 349 & 16.89 & 1135 & 54.93 & 2066 & 100.00 \\
\hline \multicolumn{9}{|c|}{ Northwest macro-region } \\
\hline 0 a 7 days & 106 & 18.89 & 432 & 52.81 & 425 & 44.22 & 963 & 41.15 \\
\hline 8 a 28 days & 278 & 49.55 & 239 & 29.22 & 326 & 33.92 & 843 & 36.03 \\
\hline$\geq 29$ days & 177 & 31.55 & 147 & 17.97 & 210 & 21.85 & 534 & 22.82 \\
\hline Total & 561 & 23.97 & 818 & 34.95 & 961 & 41.06 & 2340 & 100.00 \\
\hline
\end{tabular}


Table 3 - Main diagnoses of hospitalizations of adolescents due mental and behavioral disorders, according to macro-regional health and quadrennium, Paraná, Brazil, 2017

\begin{tabular}{|c|c|c|c|c|c|c|c|c|}
\hline & \multicolumn{2}{|c|}{$1998-2001$} & \multicolumn{2}{|c|}{$2005-2008$} & \multicolumn{2}{|c|}{$2012-2015$} & \multicolumn{2}{|c|}{ Total } \\
\hline & $\mathbf{n}$ & $\%$ & $\mathbf{n}$ & $\%$ & $\mathbf{n}$ & $\%$ & $\mathbf{n}$ & $\%$ \\
\hline \multicolumn{9}{|l|}{ Paraná } \\
\hline Mental and behavioral disorders due to the use of psychoactive substances & 2410 & 48.72 & 1820 & 55.78 & 3329 & 64.35 & 7559 & 56.48 \\
\hline Schizophrenia, schizotypal disorders and delusional disorders & 1600 & 32.34 & 706 & 21.64 & 849 & 16.41 & 3155 & 23.57 \\
\hline Mood disorders & 237 & 4.79 & 304 & 9.32 & 408 & 7.89 & 949 & 7.09 \\
\hline Organic mental disorders, including symptomatic mental disorders & 284 & 5.74 & 233 & 7.14 & 172 & 3.32 & 689 & 5.15 \\
\hline Intellectual Disability & 199 & 4.02 & 53 & 1.62 & 165 & 3.19 & 417 & 3.12 \\
\hline Other Diagnosis & 217 & 4.39 & 147 & 4.51 & 250 & 4.83 & 614 & 4.59 \\
\hline Total & 4947 & 100.0 & 3263 & 100.0 & 5173 & 100.00 & 13383 & 100.00 \\
\hline \multicolumn{9}{|l|}{ East macro-region } \\
\hline Mental and behavioral disorders due to the use of psychoactive substances & 1873 & 56.67 & 1178 & 60.85 & 1524 & 63.37 & 4575 & 59.84 \\
\hline Schizophrenia, schizotypal disorders and delusional disorders & 1016 & 30.74 & 426 & 22.00 & 606 & 25.20 & 2048 & 26.79 \\
\hline Mood disorders & 149 & 4.51 & 199 & 10.28 & 164 & 6.82 & 512 & 6.70 \\
\hline Organic mental disorders, including symptomatic mental disorders & 108 & 3.27 & 56 & 2.89 & 29 & 1.21 & 193 & 2.52 \\
\hline Intellectual Disability & 53 & 1.60 & 10 & 0.52 & 23 & 0.96 & 86 & 1.12 \\
\hline Other Diagnosis & 106 & 3.21 & 67 & 3.46 & 59 & 2.45 & 232 & 3.03 \\
\hline Total & 3305 & 100.0 & 1936 & 100.0 & 2405 & 100.00 & 7646 & 100.00 \\
\hline \multicolumn{9}{|l|}{ North macro-region } \\
\hline Mental and behavioral disorders due to the use of psychoactive substances & 119 & 23.85 & 41 & 25.63 & 480 & 71.43 & 640 & 48.08 \\
\hline Schizophrenia, schizotypal disorders and delusional disorders & 179 & 35.87 & 60 & 37.50 & 40 & 5.95 & 279 & 20.96 \\
\hline Mood disorders & 22 & 4.41 & 8 & 5.00 & 38 & 5.65 & 68 & 5.11 \\
\hline Organic mental disorders, including symptomatic mental disorders; & 84 & 16.83 & 36 & 22.50 & 57 & 8.48 & 177 & 13.30 \\
\hline Intellectual Disability & 63 & 12.63 & 1 & 0.63 & 26 & 3.87 & 90 & 6.76 \\
\hline Other Diagnosis & 32 & 6.41 & 14 & 8.75 & 31 & 4.61 & 77 & 5.79 \\
\hline Total & 499 & 100.0 & 160 & 100.0 & 672 & 100.00 & 1331 & 100.00 \\
\hline \multicolumn{9}{|l|}{ West macro-region } \\
\hline Mental and behavioral disorders due to the use of psychoactive substances & 253 & 43.47 & 188 & 53.87 & 781 & 68.81 & 1222 & 59.15 \\
\hline Schizophrenia, schizotypal disorders and delusional disorders & 194 & 33.33 & 92 & 26.36 & 93 & 8.19 & 379 & 18.34 \\
\hline Mood disorders & 31 & 5.33 & 34 & 9.74 & 86 & 7.58 & 151 & 7.31 \\
\hline Organic mental disorders, including symptomatic mental disorders; & 56 & 9.62 & 19 & 5.44 & 33 & 2.91 & 108 & 5.23 \\
\hline Intellectual Disability & 8 & 1.37 & 9 & 2.58 & 74 & 6.52 & 91 & 4.40 \\
\hline Other Diagnosis & 40 & 6.87 & 7 & 2.01 & 68 & 5.99 & 115 & 5.57 \\
\hline Total & 582 & 100.0 & 349 & 100.0 & 1135 & 100.00 & 2066 & 100.00 \\
\hline \multicolumn{9}{|l|}{ Northwest macro-region } \\
\hline Mental and behavioral disorders due to the use of psychoactive substances & 166 & 29.59 & 413 & 50.49 & 544 & 56.61 & 1123 & 47.99 \\
\hline Schizophrenia, schizotypal disorders and delusional disorders & 211 & 37.61 & 128 & 15.65 & 110 & 11.45 & 449 & 19.19 \\
\hline Mood disorders & 35 & 6.24 & 63 & 7.70 & 120 & 12.49 & 218 & 9.32 \\
\hline Organic mental disorders, including symptomatic mental disorders; & 36 & 6.42 & 122 & 14.91 & 53 & 5.52 & 211 & 9.02 \\
\hline Intellectual Disability & 75 & 13.37 & 33 & 4.03 & 42 & 4.37 & 150 & 6.41 \\
\hline Other Diagnosis & 38 & 6.77 & 59 & 7.21 & 92 & 9.57 & 189 & 8.08 \\
\hline Total & 561 & 100.0 & 818 & 100.0 & 961 & 100.00 & 2340 & 100.00 \\
\hline
\end{tabular}

Decline in hospitalizations in the first period cited was driven by several legislation that supported the closure of large psychiatric hospitals and the replacement of these services by beds in general hospitals, thus redirecting investments from SUS to health services extra-hospital, community-based care ${ }^{(12)}$.

In this area, and in order to strengthen the extra-hospital treatment, the Ordinary Law 10.216 of April 6, 2001, which provides for the protection and rights of persons with mental disorders, was approved. This clarifies that the hospitalization, both voluntary and involuntary, can only be requested by a physician and involuntary hospitalizations must be reported to the State
Public Prosecution Service. It also determines that compulsory hospitalization will only be determined by a competent judge, who must take into account the safety conditions of the patient, other hospitalized patients and staff(13).

During 2010, important events took place in the setting of Brazilian Mental Health, such as the establishment of the Ordinance 2,841, dated September 20, which established the Psychosocial Care Center for Alcohol and Other Drugs (CAPS AD III - Centro de Atenção Psicossocial de Álcool e outras Drogas) - 24 hours $^{(14)}$. CAPS AD III is a comprehensive care service that can provide full support to the individual with alcohol and drug use needs. Another 
Important Ordinance was the 2,843, dated September 20, 2010, which created the Family Health Support Centers - Modality 3 (NASF 3 - Núcleos de Apoio à Saúde da Família), with priority given to comprehensive care for users of crack, alcohol and other drugs in municipalities of population, with no capacity to implement CAPS $^{(15)}$. These facts are intriguing, as these actions should have a totally opposite impact to that evidenced in the study, since the two strategies are priority for outpatient care, being expected to reduce and not increase hospitalizations.

However, one event that may have corroborated the abrupt increase in the series was the publication in 2010 of Ordinance $2,842^{(16)}$, which approved the Norms for Operation and Enablement of Hospital Reference Services for Comprehensive Care for Alcohol Users and Others Drugs (Normas de Funcionamento e Habilitação dos Serviços Hospitalares de Referência para a Atenção Integral aos Usuários de Álcool e outras Drogas). This Ordinance approached and encouraged the regulation of accredited beds within general hospitals, with the objective of treating acute conditions resulting from the use of alcohol and other drugs. In Paraná, in 2014, there were a total of 241 beds of this type, of which 21 were specifically aimed at the care of children and adolescents ${ }^{(5)}$.

Another event that may have justified this important increase in hospitalization cases in 2010 was the fact that, in the same year, Mental Health became part of the priorities of the Ministry of Health. This event may have called the attention of health professionals to the topic, leading to a closer look at these cases, thus increasing the number of visits to adolescents and bringing as a direct consequence a greater number of referrals for these hospitalizations.

As of 2011, the time series showed a reduction in hospitalizations in all four macro-regional health centers. This fact seems to reflect the effort on the part of the state mental health management that, in 2011, prioritized the Mental Health Care Network as one of the five priority networks of the State Health Department of Paraná. This prioritization has brought advances, such as the extension of the points of care and improvements in the Permanent Education of professionals working in Mental Health ${ }^{(5)}$.

Regarding the mean length of hospital admissions, in the last four years of the study, the State and the East macro-region had the majority of hospitalizations lasting more than 29 days. This finding is contrary to what is expected, since the clinical protocol, as well as the Therapeutic Guidelines adopted by the Mental Health Care Network, provide for short-term hospitalizations ${ }^{(8)}$. One way to deal with long-term hospitalizations is to opt for psychiatric hospitalizations in general hospitals, since they have a multiprofessional team and are able to provide humanized and quality care to people who suffer from mental suffering ${ }^{(17)}$.

The study also showed a reduction in hospitalizations for schizophrenia and other schizotypal and delusional disorders, with a rise in the number of hospitalizations due to psychoactive substance use disorders, the main cause of hospitalizations in the last quadrennium. This result is in agreement with the results found in the literature. A study conducted in Paraná, from 2000 to 2015, found an increase of around $5 \%$ of these cases in the last decade ${ }^{(18)}$.

The use of psychoactive substances is currently one of the main public health problems in the world and can be considered an epidemic ${ }^{(19)}$. However, it is important to emphasize that chemical dependency does not happen instantaneously, since the user adopts patterns of consumption with progressive increase of the quantity ingested $^{(8)}$. Because of this, it is imperative that health professionals are alert to the first signs of abusive use of these substances, so they can intervene as early as possible.

In this sense, it is worth emphasizing that alcohol is the psychoactive substance most consumed by adolescents in Brazil and in the world ${ }^{(1)}$. In a study conducted in Cuba in 2013, with 288 adolescents between 10 and 14 years of age, it was evidenced that $54.5 \%$ of the interviewees had already consumed alcohol; and of these, $30.2 \%$ were between 10 and 11 years ${ }^{(4)}$.

A relevant Brazilian study, the Estudo dos Riscos Cardiovasculares em Adolescentes (ERICA - freely translated as, Study of Cardiovascular Risks in Adolescents), started in 2008, with its results published in 2016, with students aged 12 to 17 from public and private schools, showed that $21 \%$ of adolescents interviewed had consumed alcohol at least once in the last 30 days, and of these, around $25 \%$, had the first contact with the drink before 12 years of age ${ }^{(20)}$. This same survey also showed that alcohol consumption increases with the age group, which means that those adolescents who had an early initiation remain consuming and to this group are added those who start consumption later. Other relevant data showed that there was no significant difference between the consumption in the last 30 days between genders, which was observed that the male adolescents have a more frequent consumption, estimated around 10 times a month ${ }^{(20)}$.

ERICA also found that alcohol consumption among adolescents is higher in the South region ${ }^{(20)}$, which may support data from the present study. This information was reaffirmed by an exploration of the theme held in the city of Pelotas-RS ${ }^{(21)}$, which revealed that $23 \%$ of adolescents interviewed had consumed alcohol in the last 30 days, a mean higher than that indicated by ERICA.

On the consumption of other drugs in Brazil, the "VI Levantamento Nacional sobre o Consumo de Drogas entre Estudantes do Ensino Fundamental e Médio da Rede Pública e Privada nas Capitais Brasileiras" (freely translated as, VI National Survey on Drug Use among Elementary and Undergraduate Students of the Public and Private Network in the Brazilian Capitals), which identified a decrease in illicit drug use among students of public schools in the country, a fall of $49.5 \%$, compared to the survey carried out in $2004^{(22)}$.

Regardless of the cause, hospital admission is the last choice for treatment within the Mental Health Care Network, since it is known that from a first psychiatric hospitalization, the adolescent will be susceptible to new hospitalizations; and these situations bring a great personal, economic and social burden on individuals and their families. Therefore, psychiatric hospitalization should be avoided, to the maximum, especially in this age group ${ }^{(23)}$.

One strategy pointed out in the literature for the reduction of hospitalization and the search for emergency care in adolescents is the management of care by extrahospital devices specialized in the care of adolescents ${ }^{(24)}$. This is a fact of difficult applicability, given the fragility of the Mental Health Care Network and the shortage of adolescent mental health services in Paraná, only 11 CAPS $\mathrm{i}^{(5)}$.

\section{Study limitations}

It is worth highlighting the limitations imposed on work performed with secondary data, since these are generated by a system that 
depends on the quality of the data filled in the medical records and the training of those that codify the diagnoses for hospitalizations.

\section{Contributions to the field of Nursing}

Nursing has a broad and diversified scope of action in psychosocial care, with emphasis on management actions and public health policies, so that knowledge about the epidemiology of these disorders, including understanding the causality of such diseases and the greater or lesser potential of effectiveness of the actions implemented, can contribute to the qualification of this important line of care that is Mental Health.

\section{CONCLUSION}

There were large variations in hospitalization rates in the state, with an increase in hospitalizations lasting more than 29 days, and the main diagnosis was the use of psychoactive substances. Results of this study may serve to assist in the planning of public health actions aimed at reducing hospitalizations of adolescents due to mental disorders and serve as a starting point for the elaboration of new studies that identify, more precisely, the causes of the abrupt increase of hospitalizations in adolescents in 2010, besides investigating the increase in the time of permanence of these young people in hospitals.

\section{REFERENCES}

1. Schmidt MI, Duncan BB, Azevedo e Silva G, Menezes AM, Monteiro CA, Barreto SM, et al. Chronic non-communicable diseases in Brazil: burden and current challenges. Lancet. 2011;377(9781):1949-61. doi: https://doi.org/10.1016/S0140-6736(11)60135-9

2. Thiengo DL, Cavalcante MT, Lovisi GM. Prevalência de transtornos mentais entre crianças e adolescentes e fatores associados: uma revisão sistemática. J Bras Psiquiatr. 2014;63(4):360-72. doi: 10.1590/0047-2085000000046

3. Bernardinho AV, Daniel BS, Valadão GS, Santos LV, Muniz MS. Adolescência e drogadicção: uma relação cada vez mais precoce. Rev Flu Exten Univ [Internet]. 2016 [cited 2017 Sep. 10];6(1/2):36-40. Available from: http://editora.universidadedevassouras.edu.br/index.php/ RFEU/article/view/630

4. Santiesteban TB. Alcohol consumption in early adolescence and medical care. Arch Argent Pediatr. 2016;114(5):412-8. doi: 10.5546/ aap.2016.412

5. Coordenação Estadual de Saúde Mental do Paraná. A Rede de Atenção à Saúde Mental no Paraná e a competência da APS [Internet]. Curitiba; 2014 [cited 2017 nov. 03]. Available from: http://www.saude.pr.gov.br/arquivos/File/0caps/apresentacao_rede_de_saude_mental.pdf

6. Lopes CS, Abreu GA, Santos DF, Menezes PR, Carvalho KMB, Cunha CF et al. ERICA: prevalence of common mental disorders in Brazilian adolescents. Rev Saude Publica. 2016:50(Suppl 1):14s. doi: 10.1590/s01518-8787.2016050006690

7. Erse MPQA, Simões RMP, Façanha JDN, Marques LAFA, Loureiro CREC, Matos METS, et al. Depressão em adolescentes em meio escolar: Projeto + Contigo. Rev Enf Ref. 2016;serIV(9):37-45. doi: 10.12707/RIV15026

8. Secretaria de Estado da Saúde do Paraná. Linha guia de saúde mental [Internet]. Curitiba; 2014 [cited 2017 Nov 03]. Available from: http:// www.saude.pr.gov.br/arquivos/File/linha_guia_final_de_saude_mental.pdf.

9. Ministério da Saúde (BR). DATASUS - Morbidade Hospitalar no SUS por local de residência [Internet]. Brasília; 2017 [cited 2017 Nov 15]. Available from: http://tabnet.datasus.gov.br/cgi/deftohtm.exe?sih/cnv/nrpr.def

10. Ministério da Saúde (BR). Atenção Psicossocial a Crianças e Adolescentes no SUS: Tecendo Redes para Garantir Direitos [Internet]. Brasília; 2014 [cited 2016 Oct 16]. Available from: http://bvsms.saude.gov.br/bvs/publicacoes/atencao_psicossocial_criancas_adolescentes_sus.pdf

11. Instituto Brasileiro de Geografia e Estatística-IBGE. Projeções da População [Internet]. Rio de Janeiro; 2016 [cited 2016 Jul 12]. Available from: https://www.ibge.gov.br/apps/populacao/projecao/index.html

12. Duarte SL, Garcia MLT. Reforma psiquiátrica: trajetória de redução dos leitos psiquiátricos no Brasil. Emancipação. 2013;13(1):39-54. doi: 10.5212/Emancipacao.v.13i1.0003

13. Ministério da Saúde (BR). Lei n. 10.216, de 6 de abril de 2001. Dispõe sobre a proteção e os direitos das pessoas portadoras de transtornos mentais e redireciona o modelo assistencial em saúde mental [Internet]. Brasília; 2001 [cited 2015 Sep 19]. Available from: http://www. planalto.gov.br/ccivil_03/leis/leis_2001//10216.htm

14. Ministério da Saúde (BR). Portaria n. 2.841, de 20 de setembro de 2010 (Revogada pela PRT GM/MS n. 130 de 26.01.2012). Institui, no âmbito do Sistema Único de Saúde - SUS, o Centro de Atenção Psicossocial de Álcool e outras Drogas - 24 horas - CAPS AD III [Internet]. Brasília; 2010 [cited 2017 Nov 03]. Available from: http://bvsms.saude.gov.br/bvs/saudelegis/gm/2010/prt2841_20_09_2010_comp.html

15. Ministério da Saúde (BR). Portaria n. 2.843, de 20 de setembro de 2010 (Revogada pela PRT GM n. 2.488 de 21.10.2011). Cria, no âmbito do Sistema Único de Saúde - SUS, os Núcleos de Apoio à Saúde da Família - Modalidade 3 - NASF 3, com prioridade para a atenção integral para usuários de crack, álcool e outras drogas [Internet]. Brasília; 2010 [cited 2017 Nov 03]. Available from: http://bvsms.saude.gov.br/bvs/ saudelegis/gm/2010/prt2843_20_09_2010.html

16. Ministério da Saúde (BR). Portaria n. 2.842, de 20 de setembro de 2010 (Revogada pela PRT GM/MS n. 148 de 31.01.2012). Aprova as Normas de Funcionamento e Habilitação dos Serviços Hospitalares de Referência para a Atenção Integral aos Usuários de Álcool e outras Drogas - SHR ad [Internet]. Brasília; 2010 [cited 2017 Nov 03]. Available from: http://bvsms.saude.gov.br/bvs/saudelegis/gm/2010/ prt2842_20_09_2010_rep_comp.html 
17. Paes MR, Silva TL, Chaves MMN, Maftum MA. The general hospital role in the network of attention to the mental health in Brazil. Cienc Cuid Saude. 2013;12(2):407-12. doi: 10.4025/cienccuidsaude.v12i2.14207

18. Balbinot AD, Haubert A. Análise das hospitalizações por uso de drogas entre crianças e adolescentes no estado do Paraná, Brasil. Saúde Pesqui. 2016:9(1):187-194. doi: 10.177651/1983-1870.2016v9n1p187-194

19. Zoldan LGV, Araújo MR, organizadores. Uma proposta de cuidado ao dependente químico [Internet]. São Paulo: Centro de Referência de Álcool, Tabaco e outras Drogas (CRATOD); 2017 [cited 2018 Mar 12]. Available from: https://www.spdm.org.br/images/uniad/Cratod_15_ anos/CRATOD_15_ANOS.pdf

20. Coutinho ESF, França-Santos D, Magliano ES, Bloch KV, Barufaldi LA, Cunha CF, et al. ERICA: patterns of alcohol consumption in Brazilian adolescentes. Rev Saúde Publica. 2016;50(Suppl 1):8s. doi: 10.1590/s01518-8787.2016050006684

21. Strauch ES, Pinheiro RT, Silva RA, Horta BL. Alcohol use among adolescents: a population-based study. Rev Saúde Pública. 2009;43(4):64755. doi: 10.1590/S0034-89102009005000044

22. Carlini EA, organizador. VI Levantamento Nacional sobre o Consumo de Drogas Psicotrópicas entre Estudantes do Ensino Fundamental e Médio das Redes Pública e Privada de Ensino nas 27 Capitais Brasileiras - 2010 [Internet]. São Paulo: Centro Brasileiro de Informações sobre Drogas Psicotrópicas (CEBRID); 2010. Brasília: Secretaria Nacional de Políticas sobre Drogas (SENAD); 2010 [cited 2017 Aug 1]. Available from: https://www.cebrid.com.br/vi-levantamento-estudantes-2010/

23. Silveira LHC, Rocha CMF, Rocha KB, Zanardo GLP. The other side of the revolving door: community support and mental health. Psicol Estud. 2016:21(2):325-35. doi: 10.4025/psicolestud.v21i2.30660

24. Tai MH, Lee B, Onukwugha E, Zito JM, Reeves GM, Reis S. Impact of a care management entity on use of psychiatric services among youths with severe mental or behavioral disorders. Psychiatr Serv. 2018;69(11):1167-74. doi: 10.1176/appi.ps.201600539 